\title{
Does trade participation limit domestic firms' productivity gains from inward foreign direct investment?
}

\author{
René Belderbos ${ }^{1,2} \cdot$ Vincent Van Roy ${ }^{1} \cdot$ Leo Sleuwaegen $^{1}$
}

Received: 29 January 2020 / Revised: 20 June 2020 / Accepted: 22 September 2020 /

Published online: 10 November 2020

(c) The Author(s) 2020

\begin{abstract}
We examine to what extent domestic firms reap differential productivity gains from the presence of manufacturing affiliates of multinational firms in the home country (FDI spillovers), in the context of simultaneous participation in international trade through exporting and importing. FDI spillovers can occur within the industry (horizontal) and across industries due to client (forward) or supplier (backward) linkages of multinational firms, but the mechanisms underlying spillover effects may be attenuated if local firms are less reliant on inputs, clients, and competition in the domestic market. Fixed effects panel analyses on a sample of 4594 domestic Belgian firms during 2000-2007 reveal positive effects from horizontal, backward, and forward FDI spillovers on the productivity levels of domestic firms, as long as these firms do not engage in international trade. Horizontal spillovers from FDI are weaker for firms engaging in trade, while forward FDI spillovers do not benefit importing firms. Two-way traders benefit least from FDI spillovers. Forward and backward spillovers, are enhanced by human capital levels in local firms, while horizontal spillovers are reduced. The findings are broadly consistent with the notion that trade engagement and inward FDI can be substitutes in their effects on domestic firms' productivity.
\end{abstract}

Keywords Foreign direct investment $\cdot$ Trade $\cdot$ Spillovers $\cdot$ Productivity

René Belderbos

rene.belderbos@kuleuven.be

Vincent Van Roy

vincent.vanroy@kuleuven.be

Leo Sleuwaegen

leo.sleuwaegen@kuleuven.be

1 KU Leuven, Belgium

2 UNU-MERIT and Maastricht University, Maastricht, The Netherlands 


\section{Introduction}

Foreign direct investment (FDI) and trade are major conduits of international technology transfer and knowledge spillovers. Affiliates of multinational firms generally report higher productivity levels compared to their domestic firm counterparts (De Backer and Sleuwaegen 2003; Driffield 2001; Girma et al. 2001). This makes them an important source of potential knowledge spillovers to domestic firms, through diffusion of superior manufacturing practice and technology, increased competition encouraging domestic firms to become more efficient, and supplier and buyer relationships with domestic firms (Görg and Strobl 2001; Görg and Greenaway 2004; Havranek and Irsova 2011; Anwar and Nguyen 2014; Belderbos et al. 2001).

A second channel of international knowledge spillovers is through international trade, with both importing and exporting potentially associated with learning, knowledge spillovers and productivity enhancements. The import of intermediated inputs can positively affect firm productivity through learning-by-importing effects (Wagner 2012), related to access to a wider variety of inputs and equipment that are of better quality than those of the domestic counterparts (Amiti and Konings 2007; Bas and Strauss-Kahn 2014) and the exploitation of superior technologies embedded in these inputs (Halpern et al. 2015). Learning through export channels (learning-by-exporting) occurs if engagement in export markets exposes the firm to new and more rigorous demands of foreign clients and if foreign clients provide (technical) assistance in order to improve product designs and quality (e.g. Keller 2010; De Loecker 2013).

While both channels of knowledge spillovers and transfers have received ample attention in the literature, their simultaneous effects and potential interactions have not received due attention. A limited number of studies considered possible interactions at the level of the industry or country, but not at the level of the firms. ${ }^{1}$ Analyzing interactions at the micro-level is important because substitution or complementarity between trade and FDI spillovers is likely to be heterogeneous among firms with different patterns of trade participation. Hence, analysis at the industry or country level by aggregating over heterogeneous firms may obscure relevant patterns of interaction between FDI and trade.

In this paper, we examine the relationship between FDI and trade knowledge spillovers at the level of individual firms. More in particular, we analyze to what extent these two channels of learning and knowledge spillovers are substitutes, and whether substitution patterns depend on the specific trade involvement (import, export, or two-way trade) and type of FDI spillovers (backward, forward, or horizontal spillovers). Substitution may arise when firms that trade internationally may benefit less from FDI spillovers in the host country in comparison to purely domestic firms, as trading firms can obtain similar spillovers through their relationships with foreign partners and have less engagement with multinational enterprises

\footnotetext{
${ }^{1}$ E.g. Souare (2014) examined the contribution of international trade and FDI to productivity growth in Canadian manufacturing industries, while Pietrucha and Zelazny (2019) study this relationship at country level.
} 
(MNEs) operating in their country. Exporting firms may learn from foreign clients rather than from the backward linkages of foreign MNEs at home; importing firms are more likely to benefit from higher quality inputs supplied by firms abroad rather than by the forward linkages of multinational suppliers in the home country; and exporting firms are less likely to be affected by domestic competition and horizontal spillovers, as their core markets are abroad.

We test these relationships by employing fixed effects panel analysis on a representative sample of 4594 domestic Belgian firms during the period 2000-2007. Specifically, we examine the significance and impact of the three different FDI spillover channels for different groups of firms: purely domestic oriented firms (firms with no trade engagement), firms that export (only), firms that import (only), and firms with full trade involvement (both export and import). We also examine whether FDI spillovers are more salient for firms with higher human capital. Belgium is a particularly interesting country to examine given relatively high levels of productivity, trade intensity ( $80 \%$ of GDP), and the high share of manufacturing output controlled by foreign multinationals (about $50 \%$ ).

The remainder of the paper is organized as follows. The next section reviews the relevant literature and discusses how heterogeneity in trade participation of domestic firms may affect the spillovers from inward foreign investment and presents the contribution and research conjectures of our study. Section 3 proposes an empirical approach to test for this heterogeneity in FDI spillovers due to trade relationships and presents the statistical model and data against which the model is tested. Section 4 presents the estimation results. Various robustness tests are presented in Sect. 5. Section 6 provides a further interpretation of the results and concludes.

\section{Previous literature}

To gain more detailed insights on international channels of knowledge transfers, spillovers and firm productivity, we review the strands of literature on foreign direct investment and international trade.

\subsection{Inward foreign direct investment and productivity}

The presence of affiliates of foreign MNEs is often seen as a conduit for transfer of technology and knowledge within and across sectors in the host country. Technology and best practices from foreign MNEs can spill over to local competitors within the same industry (horizontal spillovers), or within vertical relationships with domestic firms as suppliers (backward spillovers) or buyers (forward spillovers). Spillovers come in many forms, such as new technologies, working methods, and management skills, and can result in improved productivity.

The results of studies analyzing spillover effects due to inward FDI have been rather ambiguous though, ranging from negative to positive depending on the data and methods used and the country that has been considered (Havranek and Irsova 2011; Irsova and Havranek 2013; Demena and van Bergeijk 2017; Rojec and Knell 
2018). ${ }^{2}$ The earliest empirical studies focused on horizontal spillovers at the industry-level and found positive associations between industry productivity and FDI in Australia (Caves 1974) and Canada (Globerman 1975). Other studies discussed the effects of FDI using well-elaborated case studies (Rhee and Belot 1990; Larrain et al. 2001), but the results of these studies lacked the potential to be generalized. Cross-sectional studies at the firm level have confirmed a positive role of horizontal spillovers in the UK and Greece, respectively (Driffield 2001; Dimelis and Louri 2002).

As highlighted by Görg and Strobl (2001), technology diffusion is a dynamic phenomenon, making panel data analysis the most appropriate method to estimate improvements in host-country firms' productivity. Using a panel of US manufacturing firms, Keller and Yeaple (2009) found a substantial influence of FDI spillovers on productivity growth. Haskel et al. (2007) similarly confirmed that the foreignaffiliate presence had a positive impact on domestic firms' total factor productivity (TFP) in UK industries. On the other hand, several other studies have reported inconclusive or even negative effects of inward FDI on local firm productivity (Girma et al. 2001; Barrios and Strobl 2002). The failure to find robust evidence for horizontal spillovers may be related to the fact that foreign multinationals have strong incentives to protect their superior technology in order to prevent leakages to local competitors (Veugelers and Cassiman 2004). Moreover, at least in the short run, the entrance of foreign multinationals may also be harmful to local firms if competition by foreign affiliates reduces growth opportunities and the potential to reap scale economies, or if foreign affiliates succeed in attracting the most qualified employees (De Backer and Sleuwaegen 2003; Kosova 2010).

The effects of backward and forward spillovers on host-country firms' productivity have also been investigated (e.g. Havranek and Irsova 2011). Most studies have focused on developing countries (e.g. Blalock 2001; Javorcik 2004; Kugler 2006; Anwar and Nguyen 2014; Alfaro 2017). In general, findings suggest (economically) significant productivity-enhancing effects of backward spillovers to local upstream firms, while there is less evidence for the existence of substantive forward spillover effects.

A number of studies have suggested that the gains from spillovers due to FDI depend on the absorptive capacity and catching-up capabilities of local firms (Görg and Greenaway 2004). According to the absorptive capacity argument of Cohen and Levinthal (1990), domestic firms need to possess a certain level of human capital and technological knowledge in order to understand, assimilate and exploit knowledge and technologies from foreign-affiliates. Domestic firms may be more able to catch-up technologically when the technology gap between both parties is not too large (Findlay 1978). In a panel of 4000 UK manufacturing firms covering the period 1991-1996, Girma et al. (2001) showed that FDI spillovers benefit domestic firms with a relatively small technology gap relative to technology leaders. Similar

\footnotetext{
${ }^{2}$ Görg and Greenaway (2004) survey the existing literature on the externalities due to inward foreign direct investment.
} 
evidence was found for Romanian (Lenaerts and Merlevede 2015) and Hungarian firms (Békés et al. 2009).

\subsection{International trade and productivity}

There also is a growing literature examining the productivity effects of firms' participation in international markets as exporters or importers. One of the main challenges has been to determine the direction of causality between international trade and firm productivity. Most of the empirical studies have been focused on exporting.

Since the seminal papers of Bernard and Jensen (1999, 1995), and Bernard and Wagner (1997) two reasons are commonly advanced to explain why exporters tend to record superior productivity performances compared to their non-exporting counterparts. The first reason relates to self-selection of the more productive firms into export markets. The argument in favor of self-selection relates to the additional costs of exporting. Entering export markets involves sunk costs linked to obtaining knowledge of foreign markets, the screening of potential customers, the set-up of foreign distribution channels and the adoption of products and services to the local needs and tastes (Kneller and Pisu 2007; Maurseth and Medin 2016). These costs act as an entry barrier, preventing less productive firms from exporting. Firms may also anticipate competition in foreign markets, introduce new technologies to obtain higher quality products and services, and hence become more productive prior to export (López 2005, 2009). The second reason relates to learning-by-exporting. Exporting firms may gain in efficiency and improve their productivity (Crespi et al. 2008; De Loecker 2013) or innovation performance (Salomon and Jin 2008; Almodóvar 2014; Belderbos and Grimpe 2020) through interactions with foreign customers and increased international competition.

Literature reviews (e.g. Wagner 2012; López 2015) conclude that the empirical evidence in favor of the selection effect is relatively clear-cut and consistent over a wide range of countries, including industrialized countries (Damijan et al. 2007; Pisu 2008; Serti and Tomasi 2008; Verardi and Wagner 2012), and transition and developing economies (Alvarez and Lopez 2005; Wilhelmsson and Kozlov 2007; Ranjan and Raychaudhuri 2011). Empirical evidence for the learning-by-exporting hypothesis is less conclusive. While several studies found beneficial effects of exporting (Girma et al. 2004; Crespi et al. 2008; Keller 2010; De Loecker 2013), other studies could not confirm positive learning-by-exporting effects (Bernard and Jensen 2004; Ruane and Sutherland 2005). Studies have also suggested that export learning may depend on firm characteristics and the pattern of exports. Baldwin and Gu (2003) and Delgado et al. (2002) found most learning to occur in younger firms. Andersson and Lööf (2009) and Castellani (2002) found learning effects most robust for firms with the highest export intensity. Learning by exporting also depends on the sophistication of exports markets and the degree of competition that firms face in these markets (Greenaway and Kneller 2007; Wagner 2012).

Similar arguments on selection and learning have been put forward to explain a positive association between import and productivity. Firms may self-select into import markets due to the fixed costs of importing, as information asymmetries 
associated with imperfect monitoring of the quality of purchased goods make the search for potential foreign suppliers costly (Altomonte and Békés 2010). In addition, importing involves costs related to the transfer and the use of technologies that are embedded in imported intermediates. The costs related to importing make it more likely that the more productive firms self-select into importing. At the same time, importing intermediate inputs may allow firms to improve their production efficiency through access to a larger variety of intermediates of higher quality and at the forefront of technology (Ethier 1982; Amiti and Konings 2007; Bas and StraussKahn 2014). Advanced imports may then serve as an important channel for knowledge and technology transfers (Aristei et al. 2013).

Empirical studies examining the relationship between imports and productivity obtained robust evidence in favor of self-selection (Altomonte and Békés 2010; Vogel and Wagner 2010), while the evidence for learning-by-importing has been less conclusive. While most studies pointed at productivity gains through importing (Lööf and Andersson 2010; McCann 2011; Augier et al. 2013; Silva et al. 2013; Forlani 2017), several studies found weak effects or effects that were only observed in the long run (Dovis and Milgram-Baleix 2009; Smeets and Warzynski 2013). Productivity gains from imports were found to be larger for firms with a stronger absorptive capacity (Okafor et al. 2017). Finally, the productivity-enhancing effects of imports may in turn increase the probability of exporting (Lo Turco and Maggioni 2013). This may explain why two-way traders are often found to be the most productive firms compared to firms that only import, only export or do not trade at all (Andersson et al. 2008; Muûls and Pisu 2009; Castellani et al. 2010; Aristei et al. 2013; Halpern et al. 2015). Two-way traders are also often integrated in global value chains, in particular in small open economies such as Belgium where exports consist for the largest part of intermediate goods (Duprez and Dresse 2013). Some studies have also looked at the moderating effect of trade policies on the magnitude of FDI spillovers and found the latter to be stronger in countries with open trade regimes (Lesher and Miroudot 2008).

\subsection{Our study}

Our research builds on previous studies and provides several original contributions to the literature on heterogeneity in the spillover effects due to inward foreign investment. We contribute to the stream of literature that has examined how structural characteristics of MNEs and domestic firms moderate spillovers from FDI (Havranek and Irsova 2011; Irsova and Havranek 2013). We refine this analysis by considering the moderating role of engagement of local firms in international markets at the micro level, i.e. the level of individual firms. Previous studies have typically assumed that export, import and FDI are channels of spillovers that add up in contributing to productivity. Most of these studies have however taken the country as unit of analysis, while they rarely considered the different channels simultaneously. ${ }^{3}$

\footnotetext{
3 One exception is a study of Pietrucha and Zelazny (2019) that explores trade (import and export) and foreign direct investment (FDI) as channels of international total factor productivity (TFP) spillovers in a cross-country analysis.
} 
At the firm level, such complementarity between trade and FDI spillovers is less obvious. On the contrary, there are good reasons to expect that the different spillover channels may substitute for each other at the level of individual firms. FDI spillover effects found at the country level may not carry over to the firm level and may provide an incomplete view by aggregating over different types of firms with heterogeneous trade involvement.

Horizontal, backward and forward vertical spillovers occur with different intensities through the various technology and knowledge diffusion channels. Four channels are commonly distinguished: demonstration and imitation, competition, supplier and client linkages effects, and training (Blomström and Kokko 1998; Rojec and Knell 2018). Demonstration and imitation effects can occur in the context of various types of relationships between MNEs and domestic firms through the access to information on production technologies and managerial or organizational knowledge stemming from collocation with MNEs in the local market. Competition effects derive from rivalry with MNEs that puts pressure on domestic firms to improve production technologies and techniques. The foreign buyer and supplier linkage effect relates to knowledge spillovers gained by domestic firms that export to sophisticated buyers MNE (Görg and Greenaway 2004), or by domestic firms purchasing sophisticated inputs from supplier MNEs. Training effects typically derive from movements of highly skilled personnel from MNEs to domestic firms (Görg and Strobl 2001).

These different mechanisms of FDI spillovers have different levels of relevance for the three types of FDI spillovers. Horizontal FDI spillovers will rely on imitation effects, hiring workers trained by MNEs subsidiaries, and competitive pressure to perform. For forward vertical spillovers, access to specialized intermediate inputs appears produced locally by MNEs is the most relevant channel (Rodriguez-Clare 1996). The most important channels of spillover effects due to backward linkages are the direct knowledge transfer, higher requirements for product quality and ontime delivery imposed by MNE clients locally (Javorcik 2004; Lall 1980; Rojec and Knell 2018).

We argue that local firms that are engaged in international trade are less exposed to interactions with MNEs in the domestic market and hence are likely to benefit less from the various mechanisms through which MNEs with a local presence generate FDI spillovers. The spillover learning and productivity benefits of local firms engaging in trade are more likely to derive from their interactions with foreign-based clients, suppliers, and rival firms rather than local subsidiaries of MNEs. Horizontal FDI spillovers can be expected to be less important for internationally trading firms, since they are exposed to competition on foreign markets and have more options to learn and imitate best practices from foreign firms than only from local MNE affiliates (Aristei et al. 2013). Domestic firms importing intermediate goods benefit through their relationship with foreign suppliers and will benefit relatively less from relationships with local MNE suppliers, on which they are less likely to rely. Exporting firms exposed to sophisticated and demanding clients in foreign markets can be 
expected to benefit less from client relationships with local MNEs and backward FDI spillovers (Blomström and Sjoholm 1999). A fortiori, firms that both import and export, especially those that are more integrated in global value chains will benefit most from their foreign trade integration, and hence can be expected to benefit least from horizontal and vertical FDI spillovers in the country, compared to purely domestic firms without such trade activities. We formulate these expectations as testable hypotheses as follows:

Horizontal FDI spillovers will be most important for domestic firms that do not import or export and will be least important for two-way traders.

Domestic firms that import will benefit less from forward FDI spillovers, and domestic firms that export will benefit less from backward FDI spillovers.

\section{Data, variables and empirical methods}

The data for our study are drawn from the BELFIRST ${ }^{4}$ database containing financial reports of all active firms in Belgium if they employ personnel. We only take into account firms with at least five employees, as the calculation of total factor productivity is less accurate for smaller firms due to less reliable reporting. We estimate our models on a balanced sample of manufacturing firms, focusing on firms that were active throughout the period 2000-2007. ${ }^{5}$ We only include domestic firms in the analysis, i.e. firms with headquarters located in Belgium. These selection screens led to a sample of 4594 domestic firms. The distribution of the sample firms over industries is roughly similar as the industry distribution of all firms in the population, and is presented in Table 1.

The dependent variable in our analysis is total factor productivity. We follow the index number method (Aw et al. 2001) to calculate total factor productivity. ${ }^{6}$ One of the advantages of the index number method is that it allows for heterogeneity in the production technology of individual firms, whilst other methods assume an identical production technology among firms within a sector. The index number method does not produce productivity levels in absolute terms but constructs an index of productivity for each firm within its sector. It quantifies the relative TFP level of a firm in a year compared to the sectoral TFP mean in a reference period. We use the first year of the sample period (2000) as reference year. We obtain producer price deflators from Eurostat and deflators for investments in fixed assets from Belgostat.

Independent variables. Consistent with earlier studies, (potential) FDI spillovers are measured as the relative presence of foreign owned affiliates. The horizontal

\footnotetext{
4 BELFIRST is the database on Belgian firms that is integrated in AMADEUS and ORBIS.

5 Analysis of selection effects did not suggest that focusing the analysis on a balanced sample leads to selection bias (see Appendix D).

${ }^{6}$ For more information concerning the alternatives to calculate total factor productivity levels, see Van Biesebroeck (2007). Details on the calculation of the TFP index are provided in Appendix A. We also attempted semi-parametric methods of Olley and Pakes and Levinshon-Petrin as alternative ways to calculate total factor productivity. Regression estimation with Olley-Pakes method proved non-robust and led to a negative estimated coefficient for fixed assets. The Levinshon-Petrin method could not be performed due to a lack of data on materials input.
} 


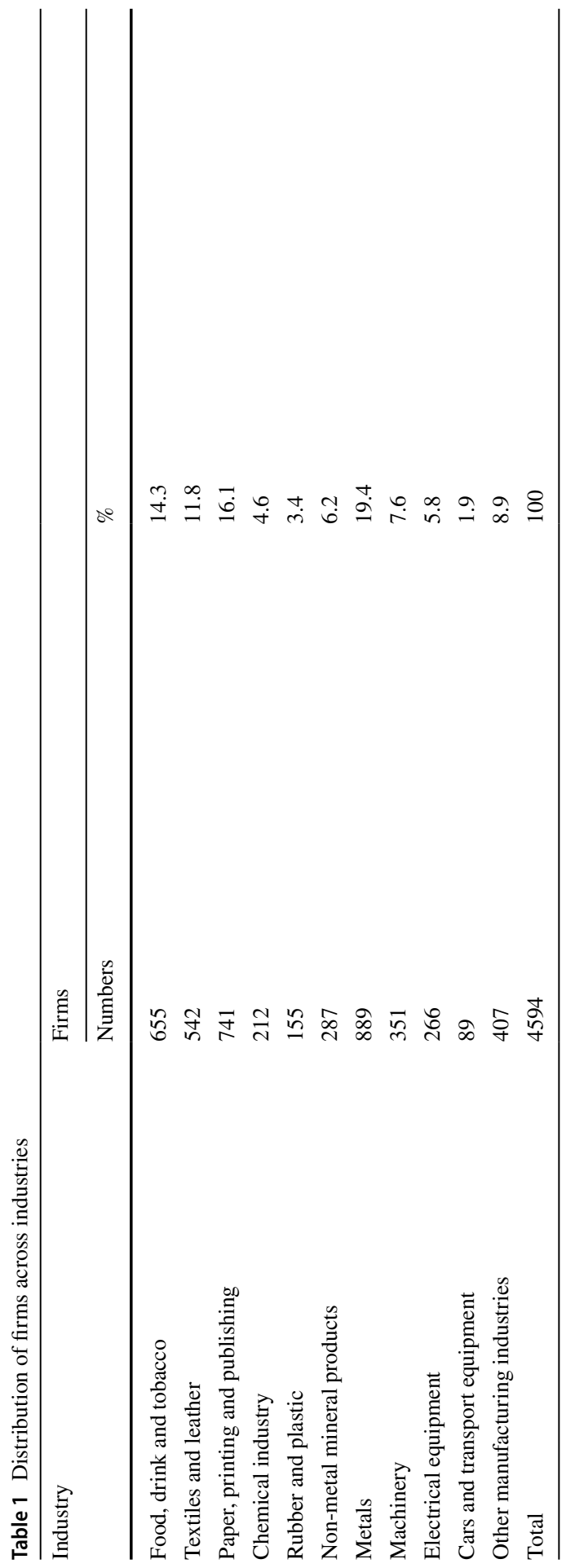


spillover measure $\left(\mathrm{HS}_{\mathrm{jt}}\right)$ is defined as the share of the output $(\mathrm{Y})$ of foreign owned affiliates in the total output of industry $j$ in period $t$ :

$$
H S_{j t}=\sum Y_{j t}^{F M N E} / \sum Y_{j t}
$$

We capture the extent of potential spillovers from foreign-owned affiliates to local suppliers (backward spillovers) by the presence of foreign affiliates in relevant downstream industries. Backward spillovers $\left(\mathrm{BS}_{\mathrm{jt}}\right)$ to sector $j$ in period $t$ are measured as the sum of the presence of foreign-owned firms in downstream industries $k$ weighted by the share of industry $j$ 's output destined for industry $k$ :

$$
B S_{j t}=\sum_{k} \alpha_{j k} H S_{k t}
$$

The parameter $\alpha_{j k}$ denotes the proportion of sector $j$ 's output supplied to sector $k$. We derive this proportion from an available input-output matrix for $2000{ }^{7}$ The backward spillover measure excludes sales within the industry, as same-sector spillovers are captured by the horizontal spillovers variable.

Finally, we measure (potential) forward FDI spillovers as the sum of presence of foreign affiliates in upstream industries, weighted by the shares of intermediate inputs that sector $j$ procures from these industries:

$$
F S_{j t}=\sum_{k} \beta_{j k} H S_{k t}
$$

where the parameter $\beta_{\mathrm{jk}}$ is the share of intermediary goods purchased by sector $j$ from sector $k$.

We control for a firm's absorptive capacity by including a firm-level indicator of human capital. We follow the approach of prior studies in measuring human capital by developing a composite indicator (Bouquet 2004; Onkelinx et al. 2016). This indicator aims to capture the aggregate knowledge, skills, abilities and other competences of a firm's workforce (Ployhart et al. 2006). It comprises the average wage level of employees, and the percentages of white-collar employees and directors in the workforce. The wage level is an indicator of the experience and skills and is calculated by dividing the total wages by the number of employees in fulltime equivalents. The percentages of white-collar employees and directors proxy for the knowledge stock of employees. ${ }^{8}$ The average wage levels and the percentages of white-collar employees and directors are divided by the respective sector averages. These three indicators are then standardized and summed up to arrive at

\footnotetext{
7 Since more recent input-output matrices are not available, we cannot take into account the changes in industry proportions over time, but it is quite unlikely that the input-output relationships between sectors have fluctuated substantially.

${ }^{8}$ Prior studies (e.g. Hitt et al., 2006, Onkelinx et al., 2016) have added the education level of the workforce to capture human capital. The education level could not be included in the composite indicator as this information was not sufficiently available in Belfirst for our sample of Belgian firms.
} 
a normalized indicator for human capital. We employ weights of 50\% for average wage levels, $35 \%$ for white-collar employees and $15 \%$ for director. ${ }^{9}$

Other variables included in the models are firm age, firm size, and a set of year dummies to control for macro-economic trends. The spillover variables are lagged by one year, as spillovers may take some time to affect productivity (Görg and Strobl 2001). ${ }^{10}$ A table with correlations of the variables is relegated to "Appendix B".

Model and Methods. We estimate fixed effects models to relate potential spillovers arising from FDI to total factor productivity:

$$
t f p_{i, t}=\alpha+\beta_{1} H S_{j, t-1}+\beta_{2} B S_{j, t-1}+\beta_{3} F S_{j, t-1}+\beta_{4} a g e_{i, t}+\beta_{5} e^{2 m p l} l_{i, t}+\beta_{6} H C_{i, t}+y_{t}+\varepsilon_{i}+v_{i, t}
$$

with small letters denote natural logarithms. The dependent variable $t f p_{i, t}$ refers to the natural logarithm of total factor productivity index of firm $i$ in year $t$. Variables $H S_{j, t-1}, B S_{j, t-1}$ and $F S_{j, t-1}$ are one-year lagged horizontal, backward and forward spillovers calculated at the NACE two-digit level. Control variables age $e_{i, t}$, empl $_{i, t}$ and $H C_{i, t}$ account for firm age, firm size and the firm's human capital, $y_{t}$ refers to year dummies to control for year-specific effects on firm productivity, $\nu_{i, t}$ is the usual error term, and $\varepsilon_{i}$ are firm fixed effects controlling for firm heterogeneity in productivity levels.

Our empirical strategy to test for differences in FDI spillovers between firms with and without trade engagement is to estimate Eq. (1) separately on different subsamples of firms: firms with no trade (i.e. no import or export activities), firms with only exports, firms with only imports, and two-way trade firms (i.e. engaged in both imports and exports). ${ }^{11}$ Subsample analysis is widely used for comparing coefficients between groups due to the advantages it offers (Greene 2008): it does not require that unexplained variance is identical between the groups of firms, and it allows the effects of the independent variables to differ between the groups, leading to consistent within-group estimates. We employ Wald tests to compare coefficients across subsamples.

Descriptives. Average total factor productivity indices by type of trade engagement, and the horizontal, backward and forward spillover measures are presented by industry (for the year 2007) in Table 2. In most sectors-exceptions are paper and printing, rubber and plastics and cars and transport equipment, the mean TFP index (in 2007) of firms engaged in export and import is significantly higher than the mean TFP of firms not engaged in trade. Industries with a strong foreign multinational firm presence are the chemicals and car and transport equipment

\footnotetext{
${ }^{9}$ Different weighting thresholds (with variations up to $15 \%$ ) have been used to test for the sensitivity of the empirical results to the composite indicator. Results remain virtually unchanged.

10 As spillover effects on domestic firms' productivity may take more time to emerge, analyses have also been conducted with two-year lags, yielding similar results. Although we estimated the FDI spillover effects with lags, we cannot fully exclude the possibility that FDI is attracted to industries with high productivity. We note that, while this would be a potential source of bias for the estimates of horizontal spillovers, this would be unlikely to extend to backward and forward spillovers due to FDI in other than the focal industry.

11 In case a firm starts or ends a specific type of trade engagement, it is re-allocated to the relevant subsample.
} 


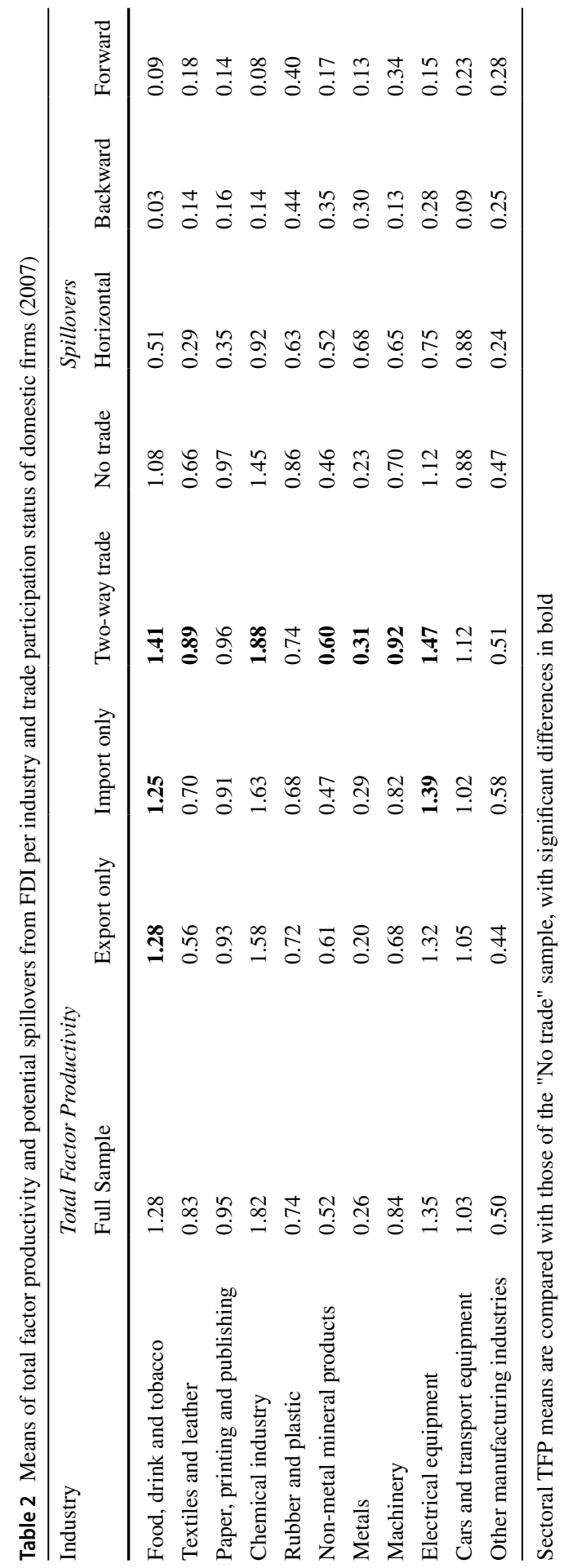


Table 3 FDI spillovers and total factor productivity of domestic firms depending on trade participation: Results of fixed effects models (2000-2007)

\begin{tabular}{|c|c|c|c|c|c|}
\hline & $\begin{array}{l}\text { (1) } \\
\text { Full sample }\end{array}$ & $\begin{array}{l}\text { (2) } \\
\text { No trade }\end{array}$ & $\begin{array}{l}\text { (3) } \\
\text { Export only }\end{array}$ & $\begin{array}{l}\text { (4) } \\
\text { Import only }\end{array}$ & $\begin{array}{l}\text { (5) } \\
\text { Two-way trade }\end{array}$ \\
\hline Horizontal spillovers & $\begin{array}{l}1.137 * * * \\
(0.034)\end{array}$ & $\begin{array}{l}1.634 * * * \\
(0.064)\end{array}$ & $\begin{array}{l}1.417 * * * \\
(0.146)\end{array}$ & $\begin{array}{l}1.151 * * * \\
(0.100)\end{array}$ & $\begin{array}{l}0.695 * * * \\
(0.052)\end{array}$ \\
\hline Backward spillovers & $\begin{array}{l}1.712 * * * \\
(0.108)\end{array}$ & $\begin{array}{l}1.662 \text { *** } \\
(0.170)\end{array}$ & $\begin{array}{l}1.363 * * * \\
(0.431)\end{array}$ & $\begin{array}{l}1.916 * * * \\
(0.262)\end{array}$ & $\begin{array}{l}1.417 * * * \\
(0.193)\end{array}$ \\
\hline Forward spillovers & $\begin{array}{l}-0.267 \\
(0.259)\end{array}$ & $\begin{array}{l}2.935^{* * *} \\
(0.562)\end{array}$ & $\begin{array}{l}2.391 * * \\
(1.028)\end{array}$ & $\begin{array}{l}-0.537 \\
(0.690)\end{array}$ & $\begin{array}{l}-1.137 * * * \\
(0.366)\end{array}$ \\
\hline Age of firm & $\begin{array}{l}0.035 * * \\
(0.014)\end{array}$ & $\begin{array}{l}0.053 * * \\
(0.023)\end{array}$ & $\begin{array}{l}0.168 * * * \\
(0.061)\end{array}$ & $\begin{array}{l}-0.022 \\
(0.051)\end{array}$ & $\begin{array}{l}0.038 \\
(0.024)\end{array}$ \\
\hline Employees & $\begin{array}{l}0.026 * * * \\
(0.008)\end{array}$ & $\begin{array}{l}-0.007 \\
(0.013)\end{array}$ & $\begin{array}{l}-0.009 \\
(0.030)\end{array}$ & $\begin{array}{l}0.058 * * * \\
(0.023)\end{array}$ & $\begin{array}{l}0.018 \\
(0.012)\end{array}$ \\
\hline Human capital index & $\begin{array}{l}0.030^{* * * *} \\
(0.004)\end{array}$ & $\begin{array}{l}0.028 * * * \\
(0.007)\end{array}$ & $\begin{array}{l}0.045 * * \\
(0.019)\end{array}$ & $\begin{array}{l}0.062 * * * \\
(0.017)\end{array}$ & $\begin{array}{l}0.018 * * * \\
(0.006)\end{array}$ \\
\hline Year 2001 & $\begin{array}{l}0.105^{* * *} \\
(0.006)\end{array}$ & $\begin{array}{l}0.100 * * * \\
(0.009)\end{array}$ & $\begin{array}{l}0.095^{* * *} \\
(0.018)\end{array}$ & $\begin{array}{l}0.102 * * * \\
(0.015)\end{array}$ & $\begin{array}{l}0.112 * * * \\
(0.009)\end{array}$ \\
\hline Year 2002 & $\begin{array}{l}0.227^{* * *} \\
(0.006)\end{array}$ & $\begin{array}{l}0.227 * * * \\
(0.010)\end{array}$ & $\begin{array}{l}0.236^{* * * *} \\
(0.023)\end{array}$ & $\begin{array}{l}0.215^{* * *} \\
(0.018)\end{array}$ & $\begin{array}{l}0.236 * * * \\
(0.009)\end{array}$ \\
\hline Year 2003 & $\begin{array}{l}0.354 * * * \\
(0.007)\end{array}$ & $\begin{array}{l}0.352 * * * \\
(0.011)\end{array}$ & $\begin{array}{l}0.358 * * * \\
(0.026)\end{array}$ & $\begin{array}{l}0.314 * * * \\
(0.019)\end{array}$ & $\begin{array}{l}0.375^{* * *} \\
(0.010)\end{array}$ \\
\hline Year 2004 & $\begin{array}{l}0.546^{* * *} \\
(0.009)\end{array}$ & $\begin{array}{l}0.584 * * * \\
(0.016)\end{array}$ & $\begin{array}{l}0.583 * * * \\
(0.035)\end{array}$ & $\begin{array}{l}0.523 * * * \\
(0.025)\end{array}$ & $\begin{array}{l}0.547 * * * \\
(0.013)\end{array}$ \\
\hline Year 2005 & $\begin{array}{l}0.659 * * * \\
(0.009)\end{array}$ & $\begin{array}{l}0.700 * * * \\
(0.017)\end{array}$ & $\begin{array}{l}0.679 * * * \\
(0.037)\end{array}$ & $\begin{array}{l}0.650 * * * \\
(0.027)\end{array}$ & $\begin{array}{l}0.663 * * * \\
(0.013)\end{array}$ \\
\hline Year 2006 & $\begin{array}{l}0.777 * * * \\
(0.010)\end{array}$ & $\begin{array}{l}0.827 * * * \\
(0.020)\end{array}$ & $\begin{array}{l}0.804 * * * \\
(0.042)\end{array}$ & $\begin{array}{l}0.762 * * * \\
(0.031)\end{array}$ & $\begin{array}{l}0.797 * * * \\
(0.015)\end{array}$ \\
\hline Year 2007 & $\begin{array}{l}0.913 * * * \\
(0.010)\end{array}$ & $\begin{array}{l}0.959 * * * \\
(0.020)\end{array}$ & $\begin{array}{l}0.936^{* * * *} \\
(0.043)\end{array}$ & $\begin{array}{l}0.887 * * * \\
(0.032)\end{array}$ & $\begin{array}{l}0.941 * * * \\
(0.015)\end{array}$ \\
\hline Constant & $\begin{array}{l}-1.154 * * * \\
(0.072)\end{array}$ & $\begin{array}{l}-1.994 * * * \\
(0.129)\end{array}$ & $\begin{array}{l}-2.005^{* * *} \\
(0.296)\end{array}$ & $\begin{array}{l}-1.144 * * * \\
(0.226)\end{array}$ & $\begin{array}{l}-0.613 \text { *** } \\
(0.115)\end{array}$ \\
\hline Observations & 30,395 & 9904 & 2593 & 3817 & 14,081 \\
\hline Number of groups & 4594 & 1772 & 753 & 912 & 2520 \\
\hline R-squared & 0.606 & 0.589 & 0.590 & 0.575 & 0.620 \\
\hline
\end{tabular}

Robust standard errors in brackets. * Significant at 10\%; ** significant at 5\%; *** significant at $1 \%$

industries, followed by the electrical equipment, metal, and machinery industries. Backward spillovers are relatively low in the food and car and transport equipment industries, as these industries generally have few industrial clients. Forward spillovers are relatively high in the rubber and plastic industry and machinery industries. 


\section{Empirical results}

The results of the fixed effects models are reported in Table 3. The first model is estimated for the full sample and serves as a comparison for the subsample analyses. The results suggest positive productivity effects for both horizontal and backward spillovers, but no productivity enhancing effect of forward spillovers (the coefficient is negative but insignificant). The results for the control variables show that more experienced, larger and skill-intensive firms have significantly higher productivity levels, as may be expected. The year dummies indicate a rising trend in total factor productivity during the period.

Columns 2-5 report results for specific sub-samples of firms depending on their international trade engagement, distinguishing firms that have no international transactions from those that only export, only import, or both export and import. The findings demonstrate important differences in the effects of FDI spillovers across these different types of firms. For domestic firms that are not engaged in trade, all channels of FDI spillovers exert a significantly positive effect on productivity, with forward spillovers showing the largest coefficient. In contrast, for two-way traders, there is a significantly negative coefficient for forward spillovers, ${ }^{12}$ while the coefficients for horizontal and vertical spillovers are smaller than those in the subsample of firms without trade.

For forward spillovers, a significant influence is notable for firms that do not import and hence are reliant on the domestic market for their intermediate inputs. In contrast, for firms importing from abroad, forward spillovers from foreign affiliates in the local economy have no significant productivity improving effect (column 4), while for firms engaging in both import and export the estimated coefficient on forward spillovers is even negative and significant, as noted above. Wald tests (reported in Appendix C) confirm that the differences in the coefficient of forward spillovers for non-trading firms on the one hand, and the coefficients for importing or importing and exporting firms on the other hand, are significant $(\mathrm{p}<0.001)$. These results suggest a substitution effect between trade engagement and FDI spillovers where it concerns forward spillovers. These results are consistent with our expectations.

The effects of backward FDI spillovers are positive and significant across all firm types. While also in this case heterogeneity is observed, with the coefficients smaller for firms with export activities as expected, Wald tests indicate that these differences are not significant, such that the results only provide qualified evidence on the moderating role of trade engagement for backward spillovers.

With respect to horizontal spillovers, we observe clear (and significant, $\mathrm{p}<0.001$ ) differences in coefficients between firms with no trade engagement on the one hand and importing firms and firms with full trade engagement on the other. The coefficient on horizontal spillovers for non-trading firms is also higher than the comparable coefficient for exporting firms, but this difference is not significant. Overall, the

\footnotetext{
12 We note that the observed negative effect does not imply an absolute decline in productivity due to MNE presence, since our measure of TFP is a firm level index relative to the industry level.
} 
Table 4 Average Predicted (Percentage) Increase in TFP due to FDI Spillovers-depending on Trade Participation

\begin{tabular}{llclc}
\hline & No trade & Export only & Import only & Two-way trade \\
\hline Horizontal FDI spillovers & 15.5 & 13.5 & 10.8 & 6.6 \\
Backward FDI spillovers & 5.8 & 4.8 & 6.6 & 4.9 \\
Forward FDI spillovers & 7.9 & 6.8 & {$[-1.7]$} & -3.2 \\
Relative TFP level & 100 (benchmark) & 106.6 & 107.3 & 121.6 \\
\hline
\end{tabular}

Percentages are predicted increases in TFP if FDI is increased from the observed minimum to the observed maximum for the industry, while keeping all other variables at their mean. []= not significant

results also provide qualified evidence for substitution between trade engagement and horizontal FDI spillovers, as conjectured in Sect. 2.

The magnitudes of the FDI spillover effects and the substitution effects between trade participation and domestic FDI spillovers are illustrated in Table 4. The numbers represent the percentage increase in TFP due to changes in FDI spillovers, and how these differ across firms with and without trade involvement. The predicted effects are calculated based on the actual observed range of FDI spillovers per industry (the difference between the industry's maximum and minimum values) during the observation period and then averaged, keeping all other variables at their mean. For comparison, the table also shows the average TFP index for the different samples of firms based on their trade engagement, benchmarked at the TFP level of firms without trade engagement. Table 4 shows that average TFP index levels are higher for exporting and importing firms compared to firms without trade engagement (106.7 and 107.3 respectively, against a benchmark of 100) and substantially higher for firms engaged in both imports and exports (121.6), illustrating the productivity advantages related to trade involvement documented in prior literature.

At the same time, the table shows that the predicted productivity gains from increases in FDI are highest for domestic firms without trade involvement: for horizontal spillovers (15.5\%), forward spillovers (7.9\%), and backward spillovers (5.8\%). The TFP increase due to horizontal spillovers is substantially smaller for firms engaged in import and export $(6.6 \%)$ but the difference is less strong with exporting firms (13.5\%). While the effects of backward spillovers do not differ much across types of firms, important differences in predicted effects of forward spillovers are observed: compared to the $7.9 \%$ for firms without trade engagement and $6.8 \%$ for exporters, there is no significant effect for importers and a 3.3\% decline for firms with full trade involvement. Hence, the lower productivity levels for firms without or with less trade engagement are at least partially compensated by higher levels of domestic FDI spillovers, illustrating the substitution effect between spillovers from trade and FDI. The high relative TFP level for firms engaged in both import and export suggests that the FDI spillovers effects for domestic firms are not such that they can fully compensate for the productivity effects of trade.

We examined the potential role of heterogeneity in the effects of spillovers due to differences in absorptive capacity. While the majority of prior studies assumed that the spillovers from FDI affected the productivity of all domestic 
firms equally, a growing number of empirical researches examine the potential role of absorptive capacity. One strand of the literature uses (indices of) R\&D information, proportion of skilled labor and training activities as a proxy for a firms' absorptive capacity (e.g. Marcin 2007; Chudnovsky et al. 2008; Augier et al. 2013; Kim 2015; Liang 2017), while another stream of studies measures absorptive capacity through the firm's technology gap with industry leaders (e.g. Girma and Görg 2005; Zhang et al. 2010). These studies argue that spillover effects may be higher for firms that have more absorptive capabilities to reap the benefits of knowledge leakages that could eventually spill over from foreign firms (Augier et al. 2013; Smith, 2014; Crescenzi et al. 2015; Liang 2017). Other studies suggest, however, that the productivity impact of technology spillovers and transfers may benefit lagging firms most, as they have more opportunities to learn and to catch up with the leaders (Griffith et al. 2009).

To examine the potential role of absorptive capacity in affecting FDI spillovers, we introduce interaction terms between the human capital index and the FDI spillover measures and present the results of this extended model in Table 5. Overall, while the results suggest differences in the magnitude of the spillover effects in accordance with a firm's human capital, the core results regarding substitution between trade and FDI spillovers remain unchanged. Our findings generally support the relevance of absorptive capacity for the effect of vertical FDI spillovers. Similar to Marcin (2007) and Liang (2017), we find that the effect of backward spillovers is more pronounced for firms with stronger absorptive capacity due to greater human capital. The interaction terms are significant in all models. For forward spillovers a similar pattern is observed, with the exception of the exporter subsample, in which the positive interaction coefficient does not reach conventional significance levels. The analysis confirms prior findings that potential negative effects of forward spillovers (in the two-way trade subsample) are significantly reduced for high absorptive capacity firms (e.g. Kim 2015). In the case of horizontal spillovers, on the other hand, we observe a very different pattern. Positive effects of FDI spillovers are reduced, rather than increased, for firms with greater human capital, although the effect sizes are rather small. This could indicate potentially more accentuated negative effects of the downside of MNE presence due the direct competition of domestic firms with MNEs: local firms with more skills and similar capabilities as MNEs may find stronger negative effects of competition on productivity by constraining growth potential as they compete for similar sophisticated parts of the markets, while they will also compete more intensively with MNE for skilled employees (De Backer and Sleuwaegen 2003; Kosova 2010).

We performed a supplementary analysis to examine the robustness of our finding. We estimated two-step models due to Heckman (1979) to test whether estimations are biased due to a non-random exit of firms from the sample during the observation period. The results are presented in Appendix D and remained unchanged in this specification, with the selection parameter insignificant in the productivity equation. 
Table 5 FDI spillovers, trade participation, and total factor productivity of domestic firms: results of Fixed Effects Models- Interaction with the human capital index

\begin{tabular}{|c|c|c|c|c|c|}
\hline & $\begin{array}{l}\text { (1) } \\
\text { Full sample }\end{array}$ & $\begin{array}{l}(2) \\
\text { No trade }\end{array}$ & $\begin{array}{l}\text { (3) } \\
\text { Export only }\end{array}$ & $\begin{array}{l}\text { (4) } \\
\text { Import only }\end{array}$ & $\begin{array}{l}\text { (5) } \\
\text { Two-way trade }\end{array}$ \\
\hline Horizontal spillover & $\begin{array}{l}1.103 * * * \\
(0.035)\end{array}$ & $\begin{array}{l}1.649 * * * \\
(0.065)\end{array}$ & $\begin{array}{l}1.413 * * * \\
(0.152)\end{array}$ & $\begin{array}{l}1.132 * * * \\
(0.103)\end{array}$ & $\begin{array}{l}0.657 * * * \\
(0.053)\end{array}$ \\
\hline $\mathrm{HS} \times \mathrm{HC}$ index & $\begin{array}{l}-0.070^{* * *} \\
(0.018)\end{array}$ & $\begin{array}{l}-0.210^{* * *} \\
(0.043)\end{array}$ & $\begin{array}{l}-0.202 * * \\
(0.092)\end{array}$ & $\begin{array}{l}-0.191 * * \\
(0.075)\end{array}$ & $\begin{array}{l}-0.063^{* * *} \\
(0.028)\end{array}$ \\
\hline Backward spillover & $\begin{array}{l}1.543 * * * \\
(0.109)\end{array}$ & $\begin{array}{l}1.581 * * * \\
(0.171)\end{array}$ & $\begin{array}{l}1.117 * * \\
(0.436)\end{array}$ & $\begin{array}{l}1.680 * * * \\
(0.267)\end{array}$ & $\begin{array}{l}1.231 * * * \\
(0.195)\end{array}$ \\
\hline $\mathrm{BS} \times \mathrm{HC}$ index & $\begin{array}{l}0.592 * * * \\
(0.052)\end{array}$ & $\begin{array}{l}0.466^{* * * *} \\
(0.086)\end{array}$ & $\begin{array}{l}0.771 * * * \\
(0.199)\end{array}$ & $\begin{array}{l}0.756^{* * * *} \\
(0.155)\end{array}$ & $\begin{array}{l}0.626 * * * \\
(0.092)\end{array}$ \\
\hline Forward spillover & $\begin{array}{l}-0.239 \\
(0.266)\end{array}$ & $\begin{array}{l}2.897 * * * \\
(0.575)\end{array}$ & $\begin{array}{l}2.613 * * \\
(1.037)\end{array}$ & $\begin{array}{l}-0.178 \\
(0.707)\end{array}$ & $\begin{array}{l}-1.132 * * * \\
(0.384)\end{array}$ \\
\hline $\mathrm{FS} \times \mathrm{HC}$ index & $\begin{array}{l}0.348 * * * \\
(0.067)\end{array}$ & $\begin{array}{l}0.396 * * * \\
(0.132)\end{array}$ & $\begin{array}{l}0.247 \\
(0.202)\end{array}$ & $\begin{array}{l}0.375^{* *} \\
(0.180)\end{array}$ & $\begin{array}{l}0.497 * * * \\
(0.123)\end{array}$ \\
\hline Age of firm & $\begin{array}{l}0.038 * * * \\
(0.014)\end{array}$ & $\begin{array}{l}0.057 * * \\
(0.022)\end{array}$ & $\begin{array}{l}0.153 * * \\
(0.061)\end{array}$ & $\begin{array}{l}-0.007 \\
(0.050)\end{array}$ & $\begin{array}{l}0.052 * * \\
(0.024)\end{array}$ \\
\hline Employees & $\begin{array}{l}0.027 * * * \\
(0.008)\end{array}$ & $\begin{array}{l}-0.008 \\
(0.013)\end{array}$ & $\begin{array}{l}-0.006 \\
(0.030)\end{array}$ & $\begin{array}{l}0.052 * * \\
(0.023)\end{array}$ & $\begin{array}{l}0.023 * \\
(0.012)\end{array}$ \\
\hline Human capital index & $\begin{array}{l}0.148^{* * * *} \\
(0.017)\end{array}$ & $\begin{array}{l}0.084 * * * \\
(0.029)\end{array}$ & $\begin{array}{l}0.108^{*} \\
(0.063)\end{array}$ & $\begin{array}{l}0.165 * * * \\
(0.058)\end{array}$ & $\begin{array}{l}0.150 * * * \\
(0.029)\end{array}$ \\
\hline Year 2001 & $\begin{array}{l}0.105^{* * * *} \\
(0.006)\end{array}$ & $\begin{array}{l}0.100 * * * \\
(0.009)\end{array}$ & $\begin{array}{l}0.097 * * * \\
(0.018)\end{array}$ & $\begin{array}{l}0.102 * * * \\
(0.015)\end{array}$ & $\begin{array}{l}0.112 * * * \\
(0.009)\end{array}$ \\
\hline Year 2002 & $\begin{array}{l}0.228 * * * \\
(0.006)\end{array}$ & $\begin{array}{l}0.227 * * * \\
(0.010)\end{array}$ & $\begin{array}{l}0.243 * * * \\
(0.023)\end{array}$ & $\begin{array}{l}0.217 * * * \\
(0.018)\end{array}$ & $\begin{array}{l}0.235^{* * * *} \\
(0.009)\end{array}$ \\
\hline Year 2003 & $\begin{array}{l}0.356 * * * \\
(0.007)\end{array}$ & $\begin{array}{l}0.350 * * * \\
(0.011)\end{array}$ & $\begin{array}{l}0.364 * * * \\
(0.026)\end{array}$ & $\begin{array}{l}0.319 * * * \\
(0.019)\end{array}$ & $\begin{array}{l}0.377 * * * \\
(0.010)\end{array}$ \\
\hline Year 2004 & $\begin{array}{l}0.545^{* * * *} \\
(0.009)\end{array}$ & $\begin{array}{l}0.580 * * * \\
(0.016)\end{array}$ & $\begin{array}{l}0.589 * * * \\
(0.035)\end{array}$ & $\begin{array}{l}0.525 * * * \\
(0.025)\end{array}$ & $\begin{array}{l}0.545^{* * * *} \\
(0.013)\end{array}$ \\
\hline Year 2005 & $\begin{array}{l}0.659 * * * \\
(0.009)\end{array}$ & $\begin{array}{l}0.694 * * * \\
(0.017)\end{array}$ & $\begin{array}{l}0.688 * * * \\
(0.037)\end{array}$ & $\begin{array}{l}0.654 * * * \\
(0.027)\end{array}$ & $\begin{array}{l}0.664 * * * \\
(0.013)\end{array}$ \\
\hline Year 2006 & $\begin{array}{l}0.778 * * * \\
(0.010)\end{array}$ & $\begin{array}{l}0.822 * * * \\
(0.020)\end{array}$ & $\begin{array}{l}0.816^{* * * *} \\
(0.042)\end{array}$ & $\begin{array}{l}0.767 * * * \\
(0.031)\end{array}$ & $\begin{array}{l}0.798 * * * \\
(0.015)\end{array}$ \\
\hline Year 2007 & $\begin{array}{l}0.916^{* * * *} \\
(0.010)\end{array}$ & $\begin{array}{l}0.955 * * * \\
(0.020)\end{array}$ & $\begin{array}{l}0.952 * * * \\
(0.043)\end{array}$ & $\begin{array}{l}0.896 * * * \\
(0.032)\end{array}$ & $\begin{array}{l}0.944 * * * \\
(0.015)\end{array}$ \\
\hline Constant & $\begin{array}{l}-1.123^{* * *} \\
(0.072)\end{array}$ & $\begin{array}{l}-1.985^{* * *} \\
(0.131)\end{array}$ & $\begin{array}{l}-1.968 * * * \\
(0.298)\end{array}$ & $\begin{array}{l}-1.187^{* * * *} \\
(0.226)\end{array}$ & $\begin{array}{l}-0.626^{* * * *} \\
(0.115)\end{array}$ \\
\hline Observations & 30,395 & 9,904 & 2,593 & 3,817 & 14,081 \\
\hline Number of groups & 4,594 & 1,772 & 753 & 912 & 2,520 \\
\hline R-squared & 0.611 & 0.592 & 0.596 & 0.581 & 0.625 \\
\hline
\end{tabular}

Robust standard errors in brackets. * Significant at 10\%; ** significant at 5\%; *** significant at $1 \%$. HS, BS, FS and HC index denote respectively horizontal spillovers, backward spillovers, forward spillovers and the human capital index 


\section{Conclusion}

Although an extensive body of literature has examined the importance of spillovers from inward foreign direct investment (FDI) in industrialized countries (Doms and Jensen 1998; Girma et al. 2001; Görg and Strobl 2001; Görg and Greenaway 2004), prior studies have not examined to what extent the spillover effects may be affected by the simultaneous involvement of domestic firms in international trade. Firms with a strong international involvement through sourcing goods and services from abroad and/or by exporting goods to foreign buyers are less dependent on the domestic economy and interactions with local affiliates of MNEs, and may be relatively less likely to benefit from spillovers due to the presence of foreign affiliates in their home country. The involvement of firms in international markets and value chains can be considered alternative channels for productivity gains and international knowledge spillovers (Bernard and Jensen 2004; Muûls and Pisu 2009; McCann 2011; De Loecker 2013; Belderbos and Grimpe 2020). Prior-aggregate level-studies could not give this detailed attention, since the relationship between trade and FDI spillovers is heterogeneous across firms and requires a micro level analysis.

Our analysis of total factor productivity, FDI spillovers, and trade engagement of Belgian firms shows that the importance of FDI spillovers indeed depends on the trade engagement of the domestic firm. On average, domestic firms benefit from horizontal and backward spillovers but effects of forward spillovers are absent (Blalock 2001; Javorcik 2004; Kugler 2006). However, forward spillovers do significantly benefit productivity of domestic firms as long as they are not engaged in import activity. Differences in the effects of FDI on productivity are also found for horizontal spillovers, with spillovers significantly smaller for firms engaged in imports and exports. Backward spillovers, in contrast, appear relatively robust across types of firms. The latter appears consistent with prior studies suggesting relatively strong effects of backward spillovers related to the active engagement of multinational affiliates in local supplier development (e.g. Javorcik 2004; Javorcik and Spatareanu 2008). Absorptive capacity as indicated by the presence of human capital positively moderates the relationship between productivity and forward as well as backward FDI spillovers, whereas a negative moderating relationship is observed for horizontal spillovers. Higher human capital may accentuate the potential downside of MNE presence due the direct competition of domestic firms with MNEs: local firms with more skills and similar capabilities as MNEs may find stronger negative effects of competition on productivity by constraining growth potential as they compete for similar sophisticated parts of the markets, while they will also compete more intensively with MNE for skilled employees (De Backer and Sleuwaegen 2003; Kosova 2010).

Our findings confirm that learning from direct trade engagement can substitute for learning and spillovers due to the presence of foreign multinationals in the local economy, in particular where it concerns the productivity benefits of sourcing intermediate goods from foreign affiliates, and the effects of local affiliates operating in domestic firms' output market. An implication is that the often ambiguous findings 
on the importance of FDI spillovers in prior studies may be due to the failure to take heterogeneity in spillover effects due to domestic firms' engagement in trade into account. Similarly, earlier mixed findings on the role of learning by exposure to international (export or import) markets may be partially due to the heterogeneous availability of alternative avenues for learning related to potential FDI spillovers in the host country. Our findings call for balanced and nuanced policies with respect to trade and FDI, in which foreign sourcing through imports, inward foreign direct investment and exports are seen as equally important instruments to upgrade activities and generate productivity growth in the local economy.

Our research has a number of limitations. First, lack of data limited our analysis to a distinction between import and export status, while we could not take into account differences in import and export intensities. Second, spillover effects are likely to differ depending on the domestic or foreign market orientation of the foreign affiliates of the MNEs. For instance, firms without trade engagement may benefit less from horizontal spillovers when foreign affiliates are mostly targeting international markets (e.g. Crescenzi et al. 2015), and there may be differences between minority owned and majority owned affiliates (Merlevede et al. 2014). Third, although we related productivity to lagged levels of FDI, we cannot fully exclude the possibility that FDI is also attracted to industries with high productivity. While this would be a source of bias for the estimates of horizontal spillover effects, perhaps this is less likely for the estimates of backward and forward spillovers, since these involve FDI in industries other than the focal industry.

We suggest that future studies explicitly differentiate the channels through which productivity gains and knowledge spillovers can be obtained and account for different risks associated with the trade and FDI channels (see e.g. Gupta et al. 2019). Such studies would preferably make use of information on the actual intensities of import and export involvement of domestic firms, going beyond the categorization of import and/or export status in the current study.

Open Access This article is licensed under a Creative Commons Attribution 4.0 International License, which permits use, sharing, adaptation, distribution and reproduction in any medium or format, as long as you give appropriate credit to the original author(s) and the source, provide a link to the Creative Commons licence, and indicate if changes were made. The images or other third party material in this article are included in the article's Creative Commons licence, unless indicated otherwise in a credit line to the material. If material is not included in the article's Creative Commons licence and your intended use is not permitted by statutory regulation or exceeds the permitted use, you will need to obtain permission directly from the copyright holder. To view a copy of this licence, visit http://creativecommons.org/licen ses/by/4.0/.

\section{Appendix}

\section{Appendix A: Total factor productivity: index number method}

To obtain comparable productivity levels across firms we use the index number method following Aw et al. (2001). Productivity levels are calculated as an index where the total factor productivity for each individual firm is compared with the 
mean TFP level in its industry in a reference period. Total factor productivity is calculated as the proportion of the value added (Y) that is not explained by the input factors (X). To obtain the TFP in an index number format, the deviation of the natural logarithm of respectively the output and input factors of firm $f$ and the arithmetic means of these factors at the industry level are taken into account (respectively $\left(\ln Y_{f t}-\overline{\ln Y_{t}}\right)$ and $\left(\ln X_{i f t}-\overline{\ln X_{i t}}\right)$, with $i$ indicating the input factor labor or capital). In order to arrive at an index that compares productivity performances with the industry mean at a certain point in time, deviations in the means over two consecutive years are chain-linked over time for both output and input factors $\left(\sum_{s=2}^{t}\left(\overline{\ln Y_{s}}-\overline{\ln Y_{s-1}}\right)\right.$ and $\sum_{s=2}^{t} \sum_{t=1}^{n}\left(\overline{\ln X_{i s}}-\overline{\ln X_{i s-1}}\right)$. The model also controls for heterogeneity in the production technology of individual firms by incorporating the respective input cost shares into the formula (denoted by the $\mathrm{S}$ factors). The formula to calculate the TFP index in its natural logarithmic form, following Aw et al. (2001, p. 11) is:

$$
\begin{aligned}
\ln T F P_{f t}= & \left(\ln Y_{f t}-\overline{\ln Y_{t}}\right)+\sum_{s=2}^{t}\left(\overline{\ln Y_{s}}-\overline{\ln Y_{s-1}}\right) \\
& \left.-\left[\sum_{i=1}^{n} \frac{1}{2}\left(S_{i f t}+\overline{S_{i t}}\right)\left(\ln X_{i f t}-\overline{\ln X_{i t}}\right)+\sum_{s=2}^{t} \sum_{t=1}^{n} \frac{1}{2} \overline{\left(S_{i s}\right.}+\overline{S_{i s-1}}\right)\left(\overline{\ln X_{i s}}-\overline{\ln X_{i s-1}}\right)\right]
\end{aligned}
$$

\begin{tabular}{|c|c|c|c|c|c|c|c|c|c|}
\hline Variables & Min & Max & (1) & (2) & (3) & (4) & (5) & (6) & \\
\hline \multicolumn{10}{|c|}{$\begin{array}{l}\text { Full sample } \\
\qquad(\mathrm{n}=30,395)\end{array}$} \\
\hline (1) & $\begin{array}{l}\text { Total factor } \\
\text { productivity }\end{array}$ & -3.860 & 4.925 & 1.000 & & & & & \\
\hline (2) & $\begin{array}{r}\text { Horizontal } \\
\text { spillover }\end{array}$ & 0.196 & 0.942 & 0.019 & 1.000 & & & & \\
\hline (3) & $\begin{array}{l}\text { Backward } \\
\text { spillover }\end{array}$ & 0.029 & 0.455 & -0.253 & 0.214 & 1.000 & & & \\
\hline (4) & $\begin{array}{l}\text { Forward } \\
\text { spillover }\end{array}$ & 0.069 & 0.408 & -0.125 & -0.142 & 0.325 & 1.000 & & \\
\hline (5) & Age of firm & 0.000 & 107 & 0.125 & -0.060 & -0.075 & -0.026 & 1.000 & \\
\hline (6) & $\begin{array}{l}\text { Number of } \\
\text { employees }\end{array}$ & 1.000 & 4220 & 0.120 & -0.015 & -0.040 & 0.021 & 0.166 & 1.000 \\
\hline \multicolumn{10}{|c|}{$\begin{array}{l}\text { Export only } \\
\text { sample } \\
(\mathrm{n}=2593)\end{array}$} \\
\hline (1) & $\begin{array}{l}\text { Total factor } \\
\text { productivity }\end{array}$ & -1.588 & 3.846 & 1.000 & & & & & \\
\hline
\end{tabular}

\section{Appendix B: Correlation tables}




\begin{tabular}{|c|c|c|c|c|c|c|c|c|c|}
\hline Variables & Min & Max & (1) & (2) & (3) & (4) & (5) & (6) & \\
\hline (2) & $\begin{array}{r}\text { Horizontal } \\
\text { spillover }\end{array}$ & 0.196 & 0.942 & -0.022 & 1.000 & & & & \\
\hline (3) & $\begin{array}{l}\text { Backward } \\
\text { spillover }\end{array}$ & 0.029 & 0.455 & -0.205 & 0.196 & 1.000 & & & \\
\hline (4) & $\begin{array}{l}\text { Forward } \\
\text { spillover }\end{array}$ & 0.069 & 0.408 & -0.164 & -0.095 & 0.316 & 1.000 & & \\
\hline (5) & Age of firm & 0.000 & 103 & 0.069 & -0.127 & -0.030 & -0.026 & 1.000 & \\
\hline (6) & $\begin{array}{l}\text { Number of } \\
\text { employees }\end{array}$ & 1.000 & 361 & 0.062 & -0.086 & 0.013 & -0.012 & 0.141 & 1.000 \\
\hline \multicolumn{10}{|c|}{$\begin{array}{l}\text { Import only } \\
\text { sample } \\
(n=3817)\end{array}$} \\
\hline (1) & $\begin{array}{l}\text { Total factor } \\
\text { productivity }\end{array}$ & -1.234 & 3.805 & 1.000 & & & & & \\
\hline (2) & $\begin{array}{r}\text { Horizontal } \\
\text { spillover }\end{array}$ & 0.196 & 0.942 & 0.022 & 1.000 & & & & \\
\hline (3) & $\begin{array}{l}\text { Backward } \\
\text { spillover }\end{array}$ & 0.029 & 0.455 & -0.252 & 0.205 & 1.000 & & & \\
\hline (4) & $\begin{array}{l}\text { Forward } \\
\text { spillover }\end{array}$ & 0.069 & 0.408 & -0.079 & -0.072 & 0.225 & 1.000 & & \\
\hline (5) & Age of firm & 0.000 & 106 & 0.118 & -0.076 & -0.128 & -0.086 & 1.000 & \\
\hline (6) & $\begin{array}{l}\text { Number of } \\
\text { employees }\end{array}$ & 2.000 & 868 & 0.016 & 0.003 & 0.011 & -0.065 & 0.109 & 1.000 \\
\hline \multicolumn{10}{|c|}{$\begin{array}{l}\text { Two-way } \\
\text { trade sample } \\
(\mathrm{n}=14,081)\end{array}$} \\
\hline (1) & $\begin{array}{l}\text { Total factor } \\
\text { productivity }\end{array}$ & -1.219 & 4.925 & 1.000 & & & & & \\
\hline (2) & $\begin{array}{r}\text { Horizontal } \\
\text { spillover }\end{array}$ & 0.196 & 0.942 & 0.093 & 1.000 & & & & \\
\hline (3) & $\begin{array}{l}\text { Backward } \\
\text { spillover }\end{array}$ & 0.029 & 0.455 & -0.257 & 0.166 & 1.000 & & & \\
\hline (4) & $\begin{array}{l}\text { Forward } \\
\text { spillover }\end{array}$ & 0.069 & 0.408 & -0.178 & -0.137 & 0.412 & 1.000 & & \\
\hline (5) & Age of firm & 0.000 & 107 & 0.096 & -0.068 & -0.080 & -0.030 & 1.000 & \\
\hline (6) & $\begin{array}{l}\text { Number of } \\
\text { employees }\end{array}$ & 2.000 & 4220 & 0.015 & -0.021 & -0.017 & -0.025 & 0.121 & 1.000 \\
\hline
\end{tabular}




\begin{tabular}{|c|c|c|c|c|c|c|c|c|c|}
\hline Variables & Min & Max & (1) & (2) & (3) & (4) & (5) & (6) & \\
\hline \multicolumn{10}{|c|}{$\begin{array}{l}\text { No trade } \\
\text { sample } \\
(n=9904)\end{array}$} \\
\hline (1) & $\begin{array}{l}\text { Total factor } \\
\text { productivity }\end{array}$ & -3.860 & 4.799 & 1.000 & & & & & \\
\hline (2) & $\begin{array}{r}\text { Horizontal } \\
\text { spillover }\end{array}$ & 0.196 & 0.942 & -0.119 & 1.000 & & & & \\
\hline (3) & $\begin{array}{r}\text { Backward } \\
\text { spillover }\end{array}$ & 0.029 & 0.455 & -0.238 & 0.307 & 1.000 & & & \\
\hline (4) & $\begin{array}{l}\text { Forward } \\
\text { spillover }\end{array}$ & 0.069 & 0.408 & -0.099 & -0.217 & 0.243 & 1.000 & & \\
\hline (5) & Age of firm & 0.000 & 93 & 0.111 & -0.037 & -0.035 & -0.053 & 1.000 & \\
\hline (6) & $\begin{array}{l}\text { Number of } \\
\text { employees }\end{array}$ & 1.000 & 900 & 0.125 & -0.050 & -0.023 & -0.009 & 0.079 & 1.000 \\
\hline
\end{tabular}

\section{Appendix C. Wald Chi-squared tests of spillover effects: comparison with firms without trade engagement}

\begin{tabular}{lclc}
\hline Comparison sample & Spillovers & & \\
& Horizontal & Backward & Forward \\
\hline Export only & 1.69 & 0.45 & 0.16 \\
Import only & $18.02^{* * *}$ & 0.65 & $18.34^{* * *}$ \\
Two-way trade & $144.22^{* * *}$ & 1.50 & $43.12^{* * *}$ \\
\hline
\end{tabular}

$* * *$ significant at $1 \%$.

\section{Appendix D: potential selection bias}

We employed a two-step estimation method developed by Heckman (1979) to examine whether estimations may suffer from a selection bias due to a non-random exit of firms from the sample. We can employ this method for the full sample estimation. In a first step, we estimated a probit model of the probability that a firm survives between 2000 and 2007. As excluding restriction we include age squared and the trade engagement dummies. From this probit model we derived the inverse Mill's ratio as the ratio of the probability density function and the cumulative distribution function, and included it in the second step as an additional explanatory variable in the model. The results presented in Table 6 show that the coefficient of the inverse Mill's ratio is insignificantly different from zero, while empirical results of the fullsample productivity model are largely unchanged. 
Table 6 Results of the Heckman selection model

\section{Heckman}

First stage

Second stage

\begin{tabular}{|c|c|c|}
\hline Horizontal spillover & $\begin{array}{l}0.164 * \\
(0.086)\end{array}$ & $\begin{array}{l}1.139 * * * \\
(0.035)\end{array}$ \\
\hline Backward spillover & $\begin{array}{l}0.463 * * * \\
(0.155)\end{array}$ & $\begin{array}{l}1.738 * * * \\
(0.109)\end{array}$ \\
\hline Forward spillover & $\begin{array}{l}-0.238 \\
(0.201)\end{array}$ & $\begin{array}{l}-0.328 \\
(0.260)\end{array}$ \\
\hline Export only & $\begin{array}{l}0.103 * \\
(0.060)\end{array}$ & \\
\hline Import only & $\begin{array}{l}0.065 \\
(0.052)\end{array}$ & \\
\hline Two-way trade & $\begin{array}{l}0.197 * * * \\
(0.042)\end{array}$ & \\
\hline Age of firm & $\begin{array}{l}0.462 * * * \\
(0.087)\end{array}$ & $\begin{array}{l}0.052 * * * \\
(0.018)\end{array}$ \\
\hline Age squared of firm & $\begin{array}{l}-0.070^{* * *} \\
(0.017)\end{array}$ & \\
\hline Number of employees & $\begin{array}{l}-0.009 \\
(0.019)\end{array}$ & $\begin{array}{l}0.026^{* * * *} \\
(0.008)\end{array}$ \\
\hline Year 2001 & & $\begin{array}{l}0.084 * * * \\
(0.015)\end{array}$ \\
\hline Year 2002 & $\begin{array}{l}-0.603^{* * *} \\
(0.060)\end{array}$ & $\begin{array}{l}0.210 * * * \\
(0.014)\end{array}$ \\
\hline Year 2003 & $\begin{array}{l}-0.568 * * * \\
(0.062)\end{array}$ & $\begin{array}{l}0.337 * * * \\
(0.014)\end{array}$ \\
\hline Year 2004 & $\begin{array}{l}-0.550^{* * *} \\
(0.062)\end{array}$ & $\begin{array}{l}0.536^{* * * *} \\
(0.013)\end{array}$ \\
\hline Year 2005 & $\begin{array}{l}-0.413^{* * *} \\
(0.066)\end{array}$ & $\begin{array}{l}0.647 * * * \\
(0.015)\end{array}$ \\
\hline Year 2006 & $\begin{array}{l}-0.478^{* * *} \\
(0.065)\end{array}$ & $\begin{array}{l}0.767 * * * \\
(0.015)\end{array}$ \\
\hline Year 2007 & $\begin{array}{l}-0.436^{* * *} \\
(0.067)\end{array}$ & $\begin{array}{l}0.914 * * * \\
(0.011)\end{array}$ \\
\hline Inverse Mill's ratio & & $\begin{array}{l}0.376 \\
(0.252)\end{array}$ \\
\hline Constant & $\begin{array}{l}1.546^{* * * *} \\
(0.142)\end{array}$ & $\begin{array}{l}-1.211^{* * *} \\
(0.082)\end{array}$ \\
\hline Observations & 33,567 & 30,395 \\
\hline Number of groups & 4791 & 4594 \\
\hline R-squared & 0.035 & 0.605 \\
\hline
\end{tabular}

Robust standard errors in parentheses

${ }^{*}$ Significant at $10 \%$; ** significant at $5 \%$; *** significant at $1 \%$ 


\section{References}

Alfaro, L. (2017). Multinational activity in emerging markets: How and when does foreign direct investment promote growth? In: J. Alcácer, B. Kogut, C. Thomas, \& B. Yeung (Eds.) Geography, Location and Strategy Advances in Strategic Management, Volume 36, Emerald Publishing Limited, 429-462.

Almodóvar, P., Saiz-Briones, J., \& Silverman, B. S. (2014). Learning through foreign market participation: The relative benefits of exporting, importing, and foreign direct investment. The Journal of Technology Transfer, 39, 915-944.

Altomonte, C., \& Békés, G. (2010). Trade complexity and productivity, Center for firms in the Global Economy - working papers 12 .

Alvarez, R., \& Lopez, R. A. (2005). Exporting and performance: evidence from Chilean plants. Canadian Journal of Economics, 38, 1384-1400.

Amiti, M., \& Konings, J. (2007). Trade liberalization, intermediate inputs, and productivity: Evidence from Indonesia. The American Economic Review, 97, 1611-1638.

Andersson, M., \& Lööf, H. (2009). Learning-by-exporting revisited: The role of intensity and persistence. Scandinavian Journal of Economics, 111, 893-916.

Andersson, M., Lööf, H., \& Johansson, S. (2008). Productivity and International Trade: Firm Level Evidence from a Small Open Economy. Review of World Economics, 144, 774-801.

Anwar, S., \& Nguyen, L. P. (2014). Is foreign direct investment productive? A case study of the regions of Vietnam. Journal of Business Research, 67(7), 1376-1387.

Aristei, D., Castellani, D., \& Franco, C. (2013). Firms' exporting and importing activities: is there a twoway relationship? Review of World Economics, 149(1), 55-84.

Augier, P., Cadot, O., \& Dovis, M. (2013). Imports and TFP at the firm level: The role of absorptive capacity. Canadian Journal of Economics, 46, 956-981.

Aw, B. Y., Chen, X., \& Roberts, M. J. (2001). Firm-level evidence on productivity differentials and turnover in Taiwanese manufacturing. Journal of Development Economics, 66, 51-86.

Baldwin, J. R., \& Gu, W. (2003). Export-market participation and productivity performance in Canadian manufacturing. Canadian Journal of Economics, 36, 634-657.

Barrios, S., \& Strobl, E. (2002). Foreign direct investment and productivity spillovers: Evidence from the Spanish experience. Weltwirtschaftliches Archiv, 138, 459-481.

Bas, M., \& Strauss-Kahn, V. (2014). Does importing more inputs raise exports? Firm-level evidence from France. Review of World Economics, 150, 241-275.

Békés, G., Kleinert, J., \& Toubal, F. (2009). Spillovers from Multinationals to Heterogeneous Domestic Firms: Evidence from Hungary. The World Economy, 32, 1408-1433.

Belderbos, R., Grimpe, C. (2020). Learning in foreign and domestic value chains: The role of opportunities and capabilities. Industrial and Corporate Change, forthcoming.

Belderbos, R., Capannelli, G., \& Fukao, K. (2001). Backward vertical linkages of foreign manufacturing affiliates: Evidence from Japanese multinationals. World Development, 29(1), 189-208.

Bernard, A. B., \& Jensen, J. B. (2004). Exporting and productivity in the USA. Oxford Review of Economic Policy, 20, 343-357.

Bernard, A. B., \& Jensen, J. B. (1999). Exceptional exporter performance: Cause, effect, or both? Journal of International Economics, 47, 1-25.

Bernard, A. B., Jensen, J. B., \& Lawrence, R. Z. (1995). Exporters, jobs, and wages in US manufacturing: 1976-1987. Brookings papers on economic activity. Microeconomics, 1995, 67-119.

Bernard, A. B., \& Wagner, J. (1997). Exports and success in German manufacturing. Weltwirtschaftliches Archiv, 133, 134-157.

Blalock, G. (2001). Technology from foreign direct investment: Strategic transfer through supply chains. UC Berkeley: Mimeo.

Blomström, M., \& Kokko, A. (1998). Multinational corporations and spillovers. Journal of Economic Surveys, 12(3), 247-277.

Blomström, M., \& Sjöholm, F. (1999). Technology transfer and spillovers: Does local participation with multinationals matter? European Economic Review, 43(4-6), 915-923.

Bouquet, C., Hebert, L., \& Delios, A. (2004). Foreign expansion in service industries: Separability and human capital intensity. Journal of Business Research, 57(1), 35-46.

Castellani, D. (2002). Export behavior and productivity growth: Evidence from Italian manufacturing firms. Weltwirtschaftliches Archiv, 138, 605-628. 
Castellani, D., Serti, F., \& Tomasi, C. (2010). Firms in international trade: Importers' and exporters' heterogeneity in Italian manufacturing industry. The World Economy, 33, 424-457.

Caves, R. E. (1974). Multinational firms, competition, and productivity in host-country markets. Economica, 41, 176-193.

Chudnovsky, D., López, A., \& Rossi, G. (2008). Foreign direct investment spillovers and the absorptive capabilities of domestic firms in the Argentine Manufacturing Sector (1992-2001). Journal of Development Studies, 44, 645-677.

Cohen, W. M., \& Levinthal, D. A. (1990). Absorptive capacity: A new perspective on learning and innovation. Administrative Science Quarterly, 35, 128-152.

Crescenzi, R., Gagliardi, L., \& Iammarino, S. (2015). Foreign multinationals and domestic innovation: Intra-industry effects and firm heterogeneity. Research Policy, 44, 596-609.

Crespi, G., Criscuolo, C., \& Haskel, J. (2008). Productivity, exporting, and the learning-by-exporting hypothesis: Direct evidence from UK firms. The Canadian Journal of Economics, 41, 619-638.

Damijan, J. P., Polanec, S., \& Prašnikar, J. (2007). Outward FDI and Productivity: Micro-evidence from Slovenia. The World Economy, 30, 135-155.

De Backer, K., \& Sleuwaegen, L. (2003). Does foreign direct investment crowd out domestic entrepreneurship? Review of Industrial Organization, 22, 67-84.

De Loecker, J. (2013). Detecting learning by exporting. American Economic Journal: Microeconomics, $5,1-21$.

Delgado, M. A., Farinas, J. C., \& Ruano, S. (2002). Firm productivity and export markets: A non-parametric approach. Journal of International Economics, 57, 397-422.

Demena, B. A., \& van Bergeijk, P. A. (2017). A meta-analysis of FDI and productivity spillovers in developing countries. Journal of Economic Surveys, 31(2), 546-571.

Dimelis, S., \& Louri, H. (2002). Foreign ownership and production efficiency: A quantile regression analysis. Oxford Economic Papers, 54, 449-469.

Doms, M. E., \& Jensen, J. B. (1998). Comparing wages, skills, and productivity between domestically and foreign-owned manufacturing establishments in the United States. In E. Robert, R. Lipsey, \& J. Richardson (Eds.), Geography and ownership as bases for economic accounting (pp. 235-258). Chicago: University of Chicago Press.

Dovis, M., \& Milgram-Baleix, J. (2009). Trade, tariffs and total factor productivity: The case of Spanish firms. The World Economy, 32, 575-605.

Driffield, N. (2001). The impact on domestic productivity of inward investment in the UK. The Manchester School, 69, 103-119.

Duprez, C., \& Dresse, L. (2013). The Belgian economy in global value chains. An exploratory analysis. National Bank of Belgium Economic Review, (ii), 07-21.

Ethier, W. J. (1982). National and international returns to scale in the modern theory of international trade. The American Economic Review, 72, 389-405.

Findlay, R. (1978). Relative backwardness, direct foreign investment, and the transfer of technology: A simple dynamic model. The Quarterly Journal of Economics, 92, 1-16.

Forlani, E. (2017). Irish firms' productivity and imported inputs. The Manchester School, 85(6), 710-743.

Girma, S., Greenaway, D., \& Kneller, R. (2004). Does exporting increase productivity? A microeconometric analysis of matched firms. Review of International Economics, 12, 855-866.

Girma, S., Greenaway, D., \& Wakelin, K. (2001). Who benefits from foreign direct investment in the UK? Scottish Journal of Political Economy, 48, 119-133.

Globerman, S. (1975). Technological diffusion in the Canadian tool and die industry. The Review of Economics and Statistics, 428-434.

Görg, H., \& Greenaway, D. (2004). Much ado about nothing? Do domestic firms really benefit from foreign direct investment? The World Bank Research Observer, 19, 171-197.

Görg, H., \& Strobl, E. (2001). Multinational companies and productivity spillovers: A meta-analysis. The Economic Journal, 111, 723-739.

Greenaway, D., \& Kneller, R. (2007). Industry differences in the effect of export market entry: Learning by exporting? Review of World Economics, 143, 416-432.

Greene, W.H. (2008). Econometric Analysis, 6th Edition. Pearson.

Griffith, R., Redding, S., \& Simpson, H. (2009). Technological catch-up and geographic proximity. Journal of Regional Science, 49, 689-720.

Gupta, R., Gozgor, G., Kaya, H., \& Demir, E. (2019). Effects of geopolitical risks on trade flows: Evidence from the gravity model. Eurasian Economic Review, 9, 515-530. 
Halpern, L., Koren, M., \& Szeidl, A. (2015). Imported inputs and productivity. The American Economic Review, 105, 3660-3703.

Haskel, J. E., Pereira, S. C., \& Slaughter, M. J. (2007). Does inward foreign direct investment boost the productivity of domestic firms? The Review of Economics and Statistics, 89, 482-496.

Havranek, T., \& Irsova, Z. (2011). Estimating vertical spillovers from FDI: Why results vary and what the true effect is. Journal of International Economics, 85(2), 234-244.

Heckman, J. J. (1979). Sample selection bias as a specification error. Econometrica, 47, 153-161.

Irsova, Z., \& Havranek, T. (2013). Determinants of horizontal spillovers from FDI: Evidence from a large meta-analysis. World Development, 42, 1-15.

Javorcik, B. (2004). Does foreign direct investment increase the productivity of domestic firms? In search of spillovers through backward linkages. The American Economic Review, 94, 605-627.

Javorcik, B., \& Spatareanu, M. (2008). To share or not to share: Does local participation matter for spillovers from foreign direct investment? Journal of Development Economics, 85, 194-217.

Keller, W. (2010). International Trade, Foreign Direct Investment, and Technology Spillovers. In: B. Hall, \& N. Rosenberg (Eds.) Handbook of the Economics of Innovation. Elsevier, Amsterdam.

Keller, W., \& Yeaple, S. R. (2009). Multinational enterprises, international trade, and productivity growth: Firm-level evidence from the United States. The Review of Economics and Statistics, 91, $821-831$.

Kneller, R., \& Pisu, M. (2007). Industrial Linkages and Export Spillovers from FDI. World Economy, 30, $105-134$.

Kosova, R. (2010). Do foreign firms crowd-out domestic firms? Evidence from the Czech Republic. Review of Economics and Statistics, 92, 861-881.

Kugler, M. (2006). Spillovers from foreign direct investment: Within or between industries? Journal of Development Economics, 80, 444-477.

Lall, S. (1980). Vertical inter-firm linkages in LDCs: An empirical study. Oxford bulletin of Economics and Statistics, 42(3), 203-226.

Larrain, F., Lopez-Calva, L., \& Rodriguez-Clare, A. (2001). Intel: A Case Study of Foreign Direct Investment in Central America. In: F. Larrain (Ed.) Economic Development in Central America. Volumen I. Harvard University Press, Cambridge.

Lenaerts, K., \& Merlevede, B. (2015). Firm size and spillover effects from foreign direct investment: The case of Romania. Small Business Economics, 45, 595-611.

Lesher, M., \& Miroudot, S. (2008). FDI Spillovers and their Interrelationships with Trade, OECD Trade Policy Papers, No. 80, OECD Publishing, Paris.

Levinsohn, J., \& Petrin, A. (2003). Estimating production functions using inputs to control for unobservables. The Review of Economic Studies, 70, 317-341.

Liang, F. H. (2017). Does foreign direct investment improve the productivity of domestic firms? Technology spillovers, industry linkages and firm capabilities. Research Policy, 46, 138-159.

Lo Turco, A., \& Maggioni, D. (2013). On the role of imports in enhancing manufacturing exports. The World Economy, 36, 93-120.

Lööf, H., \& Andersson, M. (2010). Imports, productivity and origin markets: The role of knowledgeintensive economies. The World Economy, 33, 458-481.

López, R. A. (2015). Trade and firm performance. In O. Morrissey, R. A. Lopez, \& K. Sharma (Eds.), Handbook on trade and development (pp. 129-147). Cheltenham: Edward Elgar Publishing.

López, R. A. (2009). Do firms increase productivity in order to become exporters? Oxford Bulletin of Economics and Statistics, 71, 621-642.

López, R. A. (2005). Trade and growth: Reconciling the macroeconomic and microeconomic evidence. Journal of Economic surveys, 19, 623-648.

Marcin, K. (2008). How does FDI inflow affect productivity of domestic firms? The role of horizontal and vertical spillovers, absorptive capacity and competition. The Journal of International Trade \& Economic Development, 17(1), 155-173.

Maurseth, P.B., \& Medin, H. (2016). Market-specific Sunk Export Costs: The Impact of Learning and Spillovers. The World Economy, 1-24.

McCann, F. (2011). The heterogeneous effect of international outsourcing on firm productivity. Review of World Economics, 147, 85-108.

Merlevede, B., Schoors, K., \& Spatareanu, M. (2014). FDI spillovers and time since foreign entry. World Development, 56, 108-126.

Muûls, M., \& Pisu, M. (2009). Imports and exports at the level of the firm: Evidence from Belgium. The World Economy, 32, 692-734. 
Okafor, L. E., Bhattacharya, M., \& Bloch, H. (2017). Imported intermediates, absorptive capacity and productivity: Evidence from Ghanaian manufacturing firms. The World Economy, 40, 369-392.

Olley, G. S., \& Pakes, A. (1996). The dynamics of productivity in the telecommunications equipment industry. Econometrica, 64, 1263-1297.

Onkelinx, J., Manolova, T. S., \& Edelman, L. F. (2016). Human capital and SME internationalization: Empirical evidence from Belgium. International Small Business Journal, 34(6), 818-837.

Pietrucha, J., \& Zelazny, R. (2019). TFP spillover effects via trade and FDI channels. Economic Research, $1-17$.

Pisu, M. (2008). Export destinations and learning-by-exporting: Evidence from Belgium. National Bank of Belgium Working Paper.

Ployhart, R. E., Weekley, J. A., \& Baughman, K. (2006). The structure and function of human capital emergence: A multilevel examination of the attraction-selection-attrition model. Academy of Management Journal, 49(4), 661-677.

Ranjan, P., \& Raychaudhuri, J. (2011). Self-selection vs learning: Evidence from Indian exporting firms. Indian Growth and Development Review, 4, 22-37.

Rhee, Y. W., \& Belot, T. (1990). Export catalysts in developing countries: A review of eleven success stories (p. 72). Washington, DC: World Bank. Discussion Paper no.

Rodriguez-Clare, A. (1996). Multinationals, linkages, and economic development. American Economic Review, 86(4), 852-873.

Ruane, F., \& Sutherland, J. (2005). Export performance and destination characteristics of Irish manufacturing industry. Review of World Economics, 141, 442-459.

Rojec, M., \& Knell, M. (2018). Why is there a lack of evidence on knowledge spillovers from foreign direct investment? Journal of Economic Surveys, 32(3), 579-612.

Salomon, R., \& Jin, B. (2008). Does knowledge spill to leaders or laggards? Exploring industry heterogeneity in learning by exporting. Journal of International Business Studies, 39, 132-150.

Serti, F., \& Tomasi, C. (2008). Self-selection and post-entry effects of exports: Evidence from Italian manufacturing firms. Review of World Economics, 144, 660-694.

Silva, A., Afonso, O., \& Africano, A. P. (2013). Economic performance and international trade engagement: The case of Portuguese manufacturing firms. International Economics and Economic Policy, 10, 521-547.

Smeets, V., \& Warzynski, F. (2013). Estimating productivity with multi-product firms, pricing heterogeneity and the role of international trade. Journal of International Economics, 90, 237-244.

Smith, S. W. (2014). Follow me to the innovation frontier? Leaders, laggards, and the differential effects of imports and exports on technological innovation. Journal of International Business Studies, 45, 248-274.

Souare, M. (2013). Productivity growth, trade and FDI nexus: evidence from the Canadian manufacturing sector. The Journal of Technology Transfer, 38, 675-698.

Van Biesebroeck, J. (2007). Robustness of productivity estimates. The Journal of Industrial Economics, 55, 529-569.

Verardi, V., \& Wagner, J. (2012). Productivity Premia for German manufacturing firms exporting to the euro-area and beyond: First evidence from robust fixed effects estimations. The World Economy, 35, 694-712.

Veugelers, R., \& Cassiman, B. (2004). Foreign subsidiaries as a channel of international technology diffusion: Some direct firm level evidence from Belgium. European Economic Review, 48, 455-476.

Vogel, A., \& Wagner, J. (2010). Higher productivity in importing German manufacturing firms: Selfselection, learning from importing, or both? Review of World Economics, 145, 641-665.

Wagner, J. (2012). International trade and firm performance: a survey of empirical studies since 2006. Review of World Economics, 148, 235-267.

Wilhelmsson, F., \& Kozlov, K. (2007). Exports and productivity of Russian firms: In search of causality. Economic Change and Restructuring, 40, 361-385.

Zhang, Y., Li, H., Li, Y., \& Zhou, L. A. (2010). FDI spillovers in an emerging market: The role of foreign firms' country origin diversity and domestic firms' absorptive capacity. Strategic Management Journal, 31(9), 969-989.

Publisher's Note Springer Nature remains neutral with regard to jurisdictional claims in published maps and institutional affiliations. 